\title{
Police Deprivation of Third Parties' Liberty - A Field of Tension between National Police Law and the European Convention on Human Rights, as illustrated by Austin \& Others v the United Kingdom
}

\author{
STEINAR FREDRIKSEN*
}

\section{Introduction}

In its Grand Chamber decision of 15 March 2012 in the case of Austin \& Others $v$ The United Kingdom ${ }^{1}$ the European Court of Human Rights ('the Court' or 'ECtHR') interpreted the term 'deprived of his liberty' in Article 5 (1) of the European Convention on Human Rights ('the Convention') in a way that must be seen as a restrictive interpretation, when compared to earlier case law. Based on previous case law, the police measure used in Austin would be expected to amount to deprivation of liberty, but the majority of the Court (14-3) ruled that this was not the case. Without a restrictive interpretation, the police measure in question could not have been in conformity with Article 5 (1). It was partly directed against innocent passersby who had nothing to do with the demonstration in which the measure was used, and therefore was not covered by any of the relevant grounds for justification found in Article 5 (1) subparagraphs (b) and (c).

The main purposes of this article are as follows: 1) to show that the argumentation used by the Court when reaching its restrictive interpretation very closely resembles argumentation based on norms derived from the principle of necessity; 2) to show that there can

Steinar Fredriksen is an associate professor of law at the Norwegian Police University College in Oslo. He holds his $\mathrm{PhD}$ from the University of Bergen

1 Austin \& Others $v$ the United Kingdom (GC) App nos 39692/09, 40713/09 \& 41008/09 (ECHR, 15 March 2012). 
in national police law be a close connection between the legal norms concerning police measures used for upholding security and public order, and norms derived from the principle of necessity; 3) to show that the police measure in question, even when directed against innocent passersby, would, at least in some Convention member states, be legal under national law, ${ }^{2}$ and that this state of law is closely connected to norms derived from the principle of necessity; and 4) to show that the situation described in 2) and 3) makes the Court's chosen line of argumentation in Austin a logical one.

\section{A background overview of the topics addressed in this article}

Article 5 (1) of the Convention lays down a prohibition against the deprivation of liberty. However, such deprivation of liberty can be carried out if the reason for doing so is covered by the justification found in Article 5 (1) (a-f). It is these exceptions which enable Convention states to deprive individuals of their liberty without violating the Convention, provided that such deprivation of liberty is legal according to national law.

Policing is one of the areas covered by national law where the use of deprivation of liberty is highly relevant. As far as the police task of maintaining security and public order is concerned, the most relevant subparagraphs of Article 5 (1) are (b) and (c). According to subparagraph (b), the deprivation of a persons' liberty can be effected in the case of 'non-compliance with the lawful order of a court or in order to secure the fulfilment of any obligation prescribed by law.' A typical example of the latter can be that a person is deprived of his liberty because he is disturbing public order, and thereby failing to fulfil his obligation under a national public order act to refrain from such activity. Subparagraph (c) permits the lawful arrest or detention of a person effected for the purpose of bringing him before the competent legal authority on reasonable suspicion of having committed an offence or when it is reasonably considered necessary to prevent his committing an offence or fleeing after having done so.' A relevant example here can be a person who is taken into custody because of being observed by police while committing criminal damage during a violent demonstration.

The content of subparagraphs (b) and (c) can be summed up in the following way: For a deprivation of liberty to be in conformity with these subparagraphs, the individual concerned must be doing something illegal, be suspected of having done something illegal in

2 No investigation has been made to corroborate that this is the case in every member state, but, as will be shown by examples given below, it is at least the case in some member states. 
the past, or be expected to do something illegal in the very near future. ${ }^{3}$ In most cases the use of deprivation of liberty while maintaining security and public order under national law will obviously be directed against persons who are in one of these positions, and the deprivation of liberty is thus covered by these grounds for justification. But occasionally the need will arise to deprive someone of their liberty when their activities are not illegal, or even not blameworthy. Examples can be spectators at a football match who are forced by police to remain in the stadium until supporters of the opposing team have left, or inhabitants of an apartment building who are instructed to stay inside their apartments because an armed and dangerous person is on the loose in the building. Since these individuals do not fall into the categories of people usually involved when the police deprives someone of their liberty, namely the categories 'police' and 'offenders,' they may be referred to as 'third parties.'

At least under some national legal systems, deprivation of third parties' liberty by the police, will on certain conditions be legal, either under statutory legislation or according to unwritten rules derived from the principle of necessity. Article 5 (1) of the Convention, however, contains no grounds for justification covering situations like these. The possibility of third parties being rightfully deprived of their liberty is not foreseen in the Convention. Furthermore, as we shall see in part 5 below, Article 5 (1) does not allow augmentation by unwritten rules relating to the principle of necessity. Because of this situation, a field of tension is created between Convention law and national law: deprivations of liberty directed against third parties by the police that can be legal under national law in Convention states, cannot meet the requirements set out in the Convention.

This tension was brought to the forefront when the case of Austin \& Others $v$ The United Kingdom was adjudicated by the ECtHR on 15 March 2012. The case concerned a mass demonstration (or rather, several mass demonstrations, joined into one) in London on 1 May 2001. About 2,000 people were forced to remain inside a police cordon at Oxford Circus for up to seven or eight hours, many of them innocent passersby, who had nothing to do with the demonstration. The aim of the measure was to prevent violent elements in the crowd from engaging in looting and violence.' ${ }^{4}$ The use of the cordon was legal

3 For deprivation of liberty with the purpose of securing the fulfilment of any obligation prescribed by law' to be in conformity with the Convention, the obligation in question must be 'a specific and concrete obligation which he has until then failed to satisfy' (Engel \& Others $v$ the Netherlands (PL) App nos 5100/71, 5101/71, 5102/71, 5354/72 \& 5370/72 (ECHR, 8 June 1976) para. 69). This requirement does not imply that deprivation of liberty can be justified under subparagraph (b) only after the individual has failed to fulfil his obligation. However, there must be clear indications that the obligation is going to be neglected. See, e.g., Steel \& Others $v$ the United Kingdom App no 24838/94 (ECHR, 23 September 1998) para. 64: '[...] it would not appear that there was anything in their behaviour which could have justified the police in fearing that a breach of the peace was likely to be caused.'

$4 \quad$ Austin, para.18. 
under English law (see IV B below), but the applicants in the case claimed to have been subjected to deprivation of liberty inconsistent with Article 5 (1) of the Convention. If this was the case, the use of the police cordon could not be legal under the Convention. As has already been mentioned, the majority of the Court solved the tension between the two sets of norms by introducing a certain technique for restrictive interpretation of the term 'deprived of his liberty', and thereby found that the use of the police cordon did not amount to deprivation of liberty, the consequence being that there was no need for any ground for justification.

\section{The Relationship between the Principle of Necessity and National Norms Governing the Maintenance of Security and Public Order in a Political-Philosophical and Historical Perspective}

There is a close relationship between the principle of necessity and police law concerning security and public order, both historically and political-philosophically. In the perspective of political philosophy, policing in the field of security and public order can be seen as constituted of a set of measures aimed at counteracting a continuing series of states of emergency. Each occurring threat against security and public order create, so to speak, a state of emergency on a micro-level, against which the police must react as a matter of necessity. ${ }^{5}$

The maintenance of security and public order has in several countries and in different contexts, from philosophical discussions in Germany, France and England, dating back at least to the 18th century, through to legislative discussions carried out by Norwegian MPs from the early 19th century until 1995, been considered a subject poorly suited for legislation. ${ }^{6}$ These opinions have in various ways been related to the difficulty in foreseeing the many diverse situations where police interference may be necessary, as well as difficulty in foreseeing the kinds of measures the police may have to resort to. As a result this field of police law has come to be seen as belonging to the domain of 'necessity.' In some states police intervention outside of the scope of codes of criminal procedure has only recently (during the last 10-25 years) been regulated by legislation, and prior to this legislation the primary source of national law in this field was some kind of 'general

5 See Heivoll, Den norske forfatningsstatens politimyndighet - fremveksten av en apori? Fremveksten av norsk politimyndighet i lys av Giorgio Agambens begreper om suverenitet og unntakstilstand, in Unntakstilstand og forfatning. Brudd og kontinuitet $i$ konstitusjonell rett, ed. Dag Michalsen (Pax 2013) pp. 337-346.

6 See Heivoll, Sondringen mellom kriminalforbrytelser og politiforseelser. Getz, straffelovkommisjonen og etableringen av en ny strafferett, in Straff, lov, historie. Historiske perspektiver på straffeloven av 1902, eds. Flaatten and Heivoll (Akademisk Publisering 2014) pp. 309-342. See also Fredriksen, Ro, orden og frihet - En fremstilling av politiets adgang til å gripe inn i den personlige frihet ved utførelse av ordenstjeneste (Gyldendal Juridisk 2015) pp. 491-499. 
clause,' written or unwritten. ${ }^{7}$ The core content of such general clauses was, firstly, that the police were permitted to use infringing measures while maintaining security and public order. This was at least partly built on the argument that because the police were by law given the task to uphold security and public order, they also had to possess the necessary powers of enforcement required ('implied powers'). Secondly, a core element of the general clauses was that the measures used in upholding security and public order had to be necessary and proportionate.

Under the gradually increasing influence of the principle of legality, understood as a requirement for any encroachment by public authorities in individuals' private sphere to have a basis in formal legislation, the general clauses came in several states to be felt as an inadequate source of law, and, as already mentioned, have been replaced by legislation. This legislation, however, is clearly marked by the difficulties that were in the past used as arguments against any legislation in this field of law (or even against considering the maintenance of security and public order as a field of law at all). The use of vague terms like 'security' and 'public order' in statutes, as well as the fact that the measures listed as available to the police are in some cases not meant to be exhaustive, ${ }^{8}$ are examples of this. These characteristics can be seen as manifestations of the principle of necessity, which still today plays a prominent role in national police law, as far as maintaining security and public order is concerned.

7 For example, Norway got its first police act regulating the use of infringing police measures outside the Code of Criminal Procedure in 1995 and Denmark in 2004, while the police act of Sweden dates from 1988. Finland, however, got its police law regulating the use of police measures as early as 1967 . (The Finnish police act has since been replaced by the police act of 1995, and then by the police act of 2011.) In Switzerland a general clause still exist, but national courts have proclaimed that it can only be used in cases of emergency ('Notlagen'). (On the existence and contents of the Swiss general clause, see Gsell v Switzerland App no 12675/05 (ECHR, 8 October 2009) paras. 29-32.) On the Norwegian general clause, see Fredriksen 2015 pp. 35-37, with references to relevant literature regarding the Swedish and Finnish general clauses.

$8 \quad$ See e.g., the Norwegian Police Act of 4 August $1995 \$ 7$ and the Danish Police Act of 9 June 2004 $\$ 5$, which both state that the measures listed are 'among others' that can be used by the police in maintaining security and public order. 
Bergen Journal of Criminal Law and Criminal Justice $\bullet$ 1/2015

\section{The Principle of Necessity and the Power to use Police Measures di- rected against Third Parties under National Police Law}

\subsection{Introduction}

One element in norms derived from the principle of necessity is that they can acknowledge the right to carry out the act of necessity in such a way that it disadvantageously affects third parties. ${ }^{9}$ This is the aspect of necessity-based norms in national police law that is significant in the context discussed here, and the reason for which the tension displayed in Austin occurred: under national law the many people trapped in the police cordon that had nothing to do with the demonstration could legally be subjected to this police measure, according to norms based on the principle of necessity, but if the measure in question amounted to a deprivation of liberty, as previous ECtHR case-law would suggest, the measure could not be compatible with the Convention.

\subsection{Police Measures against Third Parties in the Context of Legal Principles}

The legal principle which in English can be termed as the 'disturber' principle, is an important foundation in police law regulating the maintenance of security and public order. ${ }^{10}$ In legal systems using the German language it is commonly known as 'Stöhrerprinzip' or 'Verursacherprinzip.' ${ }^{11}$ This principle expresses the fundamental obligation of the police to direct its measures against the person or persons responsible for the threat or disturbance in question. A simple example may be the following: if two persons are disturbing the peace in a public park, police measures must be directed against these persons, e.g. by ordering them to leave the park. The police cannot instead close the park to members of the public, so as to shield them from the ongoing disturbance. The 'responsibility' can, as in this example, be connected to illegal behaviour, but does not necessarily contain any such illegal element. If a curious onlooker goes so close to the edge of a landslide that his personal security is in danger, the police can order him away, although no law obliges him to stay away from the edge. The onlooker can even be the subject of police measures if he himself unaware of the landslide, and thereby in no way

9 See e.g., regarding English criminal law, Ashworth, Principles of Criminal Law (Sixth ed., Oxford University Press 2009) p. 130, and, regarding Norwegian criminal law, Andenæs, Alminnelig strafferett (Fifth ed., Universitetsforlaget 2004) 180, 183.

$10 \quad$ Fredriksen 2015, pp. 259-263.

$11 \quad$ Fredriksen 2015, p. 261, note 358. 
is to be blamed for his behaviour. ${ }^{12}$ In this example the onlooker is a 'disturber' because he sets himself in a position where his security is threatened, but he is not an 'offender', in the meaning of violating any laws. He is accordingly someone which in part 2 above was described as a 'third party.' The reason for which the 'disturber' principle can be interpreted in a way that makes it possible to direct police measures against 'disturbers' who are not 'offenders,' must be sought in the principle of necessity. When the two principles are balanced against each other, 'necessity' can lead to the interpretation that an individual can be a 'disturber' without violating any laws. ${ }^{13}$

The balancing of the 'disturber' principle against the principle of necessity can in a given situation lead to an outcome entirely in favour of the latter. In other words, the principle of necessity can lead to a situation where the 'disturber' principle is set aside, and police measures are directed against third parties who in no ordinary meaning of the word can be said to be 'disturbers.' Such third parties can be inter alia the innocent passerby who happened to be at Oxford Circus when the police cordon was used on 1 May 2001.

With regards to third parties, the concrete outcome of a balancing between the 'disturber'-principle and the principle of necessity will depend on the requirement of proportionality, which must be considered to be an integral part of the principle of necessity when 'necessity'-based norms are used as the legal basis for actions taken by state authorities against individuals (see also part 9.3.1 below). When this balancing act is carried out it will be of considerable importance whether the measure is directed against an 'offender' or against a third party. When it is directed against a third party, it will be relevant for the proportionality assessment whether the action taken against the third party is in his own interest, e.g. for the protection of his personal security, or in the interest of some form of common good, e.g. for the protection of other people's properties against criminal damage. The proportionality assessment may lead to the conclusion that the use of a measure infringing on the rights and freedoms of a third party is more acceptable when it is carried out in his interest, rather than in the interest of others.

12 Gusy, Polizei- und Ordnungsrecht (7. Auflage, Mohr Siebeck 2009) p. 170: 'Ausgangspunkt ist dabei, dass die Gefahrursache in zurechenbarer Weise der Risikosphäre eines potentiell Verantwortlichen enstammt. Die Verantwortlichkeit in diesem Sinne ist weder Grundlage von Schadensersatzansprüchen Dritter noch von strafrechtlichen Sanktionen. Denn das Polizei- und Ordnungsrecht fordert weder vorsätzliches noch schuldhaftes Handeln.'

13 On the balancing of competing legal principles, see Alexy, On the Structure of Legal Principles, in 13 Ratio Juris (No. 3, September 2000), pp. 294-304. 
Bergen Journal of Criminal Law and Criminal Justice $\bullet$ 1/2015

\subsection{Police Measures against Third Parties in the Context of Norms, illustrated by Examples from English, Norwegian and Danish Law}

As a result of the above mentioned balancing in the context of legal principles, national law can contain norms making it legal for police to use infringing measures against third parties. This was for example found to be the situation when the English High Court pronounced its judgement in the Austin case. In that ruling, 'necessity' under English common law was found to constitute a defence against a claim of 'false imprisonment' by the claimants in the case. These were claimants who not only had not broken any obligation prescribed by law, but who also seem to have been considered by the court as 'third parties' in the conflict between the police and the (potentially) violent demonstrators. ${ }^{14}$

The section of the Norwegian Police Act of 4 August 1995 which is most central when upholding security and public order (section 7), does not provide any specific categories of individuals against whom measures under the act can be directed, and thus enables the interpretation, founded on the principle of necessity, that infringing measures can also be used against third parties, provided that this is necessary and proportionate. In addition, unwritten rules derived from the principle of necessity can lead to the same result. ${ }^{15}$

The Danish Police Act of 9 June 2004 provides that police measures aimed at upholding security and public order must be directed against the person or persons who give rise to the danger. ${ }^{16}$ This means that, unlike the situation in Norwegian police law, the 'disturber' principle is under Danish police law confirmed by legislation, although it is not restricted to situations where the individual in question has failed to fulfill 'any obligationprescribed by law'. Nonetheless, as is the case under Norwegian law, police measures aimed at upholding security and public order can be directed against third parties under Danish law, following unwritten rules based on 'necessity.' ${ }^{17}$

In all instances such as these, were infringements on third parties' rights and freedoms are legal under national police law, either by legislation or by unwritten norms derived from the principle of necessity, the legality of such infringements in a concrete situation will depend on the outcome of an assessment of proportionality, as described in B above. Legality in general can never automatically lead to legality in a concrete situation.

14 England and Wales High Court Decision, [2005] EWHC 480 (QB), (23 March 2005) pp. 49-55, 156 and 573-580.

15 On the subject of unwritten 'necessity'-based rules in Norwegian police law, see, e.g., NOU 2004: 6 Mellom effektivitet og personvern, pp. 45-46. (law commitee report)

16 Danish Police Act of 9 June 2004. See inter alia sections 5 (2), 8 (1) and (3), and 9 (2).

17 Henricson, Politiloven med kommentarer (Second ed., Jurist- og økonomforbundets forlag 2010) pp. 29-30. 


\section{The Principle of Necessity in Convention Law}

Norms derived from the principle of necessity also have a central place in Convention law, although the background for this is entirely different than for those norms of national police law based on 'necessity.' The former 'general clauses' of national police law did not have any bearing on the drafting of Convention norms, and neither were these drafted with specific authorities such as the police in mind. They are, on the contrary, general.

One example of a 'necessity' element in Convention law is the way restrictions on Convention rights and freedoms are drafted in several of the articles. This can be illustrated by Article 2 of Protocol 4 to the Convention, which regards freedom of movement. (The subject of this article is restrictions on freedom, as opposed to deprivations of freedom, dealt with in Article 5 of the Convention, see part 7 below.) Article P4-2(3) stipulates that restrictions on the freedom of movement are prohibited unless they are

'in accordance with law and are necessary in a democratic society in the interests of national security or public safety, for the maintenance of ordre public, for the prevention of crime, for the protection of health or morals, or for the protection of the rights and freedoms of others.'

The interesting point in this quotation is not the use of the word 'necessary.' In this context, this word serves the purpose of limiting the possibility to place restrictions on the freedom of movement, not to make such restrictions legal. The point of interest lies rather in the fact that the criteria under which restrictions are permissible are open and unspecific. The criteria are also written in a way that does not exclude the use of restrictions on freedom of movement directed against those individuals which we in this article have referred to as 'third parties.' The starting point for interpretation, here as in national law, will have to be the 'disturber' principle, but after a concrete assessment of proportionality, the outcome could be that restrictions on the freedom of movement can be imposed on third parties under Article P4-2(3). Had the question in Austin been whether the use of the police cordon, affecting innocent passersby, was legal under Article P4-2(3), the answer could with great certainty have been affirmative. ${ }^{18}$

The wording of Article 5 (1) stands in stark contrast to articles like the one we have now discussed. This contrast was clearly intended, as the parties to the Convention seem to have been of the opinion that deprivations of liberty are such serious infringements on the rights of individuals that the criteria governing their use must be specified in detail in the text of the Convention. One of these criteria is, as we have seen, the requirement that a deprivation of liberty under subparagraph (b) must be related to the non-fulfilment of an obligation prescribed by law. This excludes the use of deprivation of freedom against

18 The question of infringement on the freedom of movement provided for in Article P4-2 did not arise in Austin, as the United Kingdom has not ratified Protocol 4 (Austin, para. 55). 
third parties, as Article 5 (1) (b) embodies the 'disturber'-principle in its strictest possible form. This contrast to Art. P4-2 also invites the conclusion that what constitutes necessary infringements on the right to liberty is exhaustively listed in Article 5 (1) (a-f) - or as the dissenting judges in Austin expressed this: that [ ...], the wording of Article 5 in itself strikes the fair balance inherent in the Convention between the public interest and the individual right to liberty by expressly limiting the purposes listed which a deprivation of liberty may legitimately pursue'. ${ }^{19}$ In other words: unlike national police law, and unlike the situation regarding exemptions from many other rights and freedoms guaranteed by the Convention, Article 5 (1) leaves no room for supplementation by unwritten 'necessity'-based norms, which could have opened the way for depriving third parties of their freedom.

\section{The Case of Austin \& Others $v$ The United Kingdom}

In its judgement in Austin, the majority of the Court ruled that the use of a police cordon, also known as 'kettling,' ${ }^{20}$ in London's Oxford Circus on 1 May 2001, did not amount to a deprivation of liberty under Article 5 (1) of the Convention. In light of the Court's previous case law regarding what constitutes deprivation of liberty, this outcome can be perceived as somewhat surprising, considering, i.e., that on this particular occasion, the kettle' meant that about 2,000 people, potentially violent participants in an illegal demonstration as well as innocent passersby, were forced to remain within the police cordon under difficult conditions for as much as between seven and eight hours. The three dissenting judges found that the 'kettle' did indeed constitute deprivation of liberty, and accordingly was in breach of the Convention. ${ }^{21}$

The Metropolitan police had been notified of two May Day arrangements that were to take place on 1 May 2001. Since notification had been given, these arrangements were legal under English law. ${ }^{22}$ However, the police had intelligence indicating that in addition to these arrangements, there would also be held illegal and potentially violent demonstrations by a broad coalition of environmentalist, anarchist and left-wing protest groups. ${ }^{23}$ Demonstrations were to be held on several sites around London, and the participants

Austin \& Others $v$ the United Kingdom (Joint Dissenting Opinion of Judges Tulkens, Spielmann and Garlicki) App nos 39692/09, 40713/09 \& 41008/09 (ECHR, 15 March 2012), para. 4.

20 Wikipedia offers the following definition of 'kettling': 'Kettling (also known as containment or corralling) is a police tactic for controlling large crowds during demonstrations or protests. It involves the formation of large cordons of police officers who move to contain a crowd within a limited area. Protesters are left only one choice of exit controlled by the police - or are completely prevented from leaving, [...].' See http://en.wikipedia.org/wiki/Kettling (last visited 15 April 2015).

$21 \quad$ Austin, Joint Dissenting Opinion para. 15.

22 Public Order Act 1986, section 11.

23 Austin, para. 18. 
in all these demonstrations were to gather at Oxford Circus at 4 p.m. As it turned out, people began arriving at Oxford Circus much earlier, and at $2 \mathrm{p} . \mathrm{m}$. the police decided to put up a cordon to contain the crowd. ${ }^{24}$ Some of the people caught in the cordon were participants in the illegal demonstrations, but, given the nature of the measure in use, it was unavoidable that several people who had nothing to do with the demonstration were caught up inside the cordon. Three of the four applicants in Austin were passersby, one of whom was on his way to a bookshop, and two were trying to get back to work after their lunch breaks. ${ }^{25} \mathrm{On}$ the other hand many of the demonstrators remained outside the cordon. ${ }^{26}$ The police made several attempts at opening up the cordon, but every attempt led to violence occurring on both the inside and the outside. As a consequence, the last remaining people in the cordon were not released until about 9.45 p.m. ${ }^{27}$ This meant that a large number of people were forced to stay inside the cordon, in cold weather and rain, and without access to food, water or toilet facilities, for as much as seven to eight hours.

\section{The Distinction between Deprivation of Liberty and Restrictions on the Freedom of Movement, According to Previous ECtHR Case-Law}

The subject of Article 5 of the Convention is a person's physical liberty to move from place to place..$^{28}$ More specifically, Article 5 deals with deprivation of such liberty, as opposed to other kinds of restrictions upon the physical liberty to move from place to place. This follows not only from the wording of Article 5 itself ('No one shall be deprived of his liberty ...'), but also from the fact that other restrictions on liberty than the deprivation thereof are covered by Article 2 of Protocol 4 to the Convention, concerning the 'Freedom of movement.'

As was briefly mentioned above, the outcome in Austin, i.e. that the 'kettling' in question did not amount to deprivation of liberty, can be surprising, given the Court's previous case-law on this subject. In a series of decisions, the Court has based its interpretation of the term 'deprived of his liberty' in Article 5 (1) on a certain set of criteria, established in Engel \& Others $v$ the Netherlands ${ }^{29}$ and Guzzardi v Italy, ${ }^{30}$ which previously had never been departed from. In those decisions it was established that

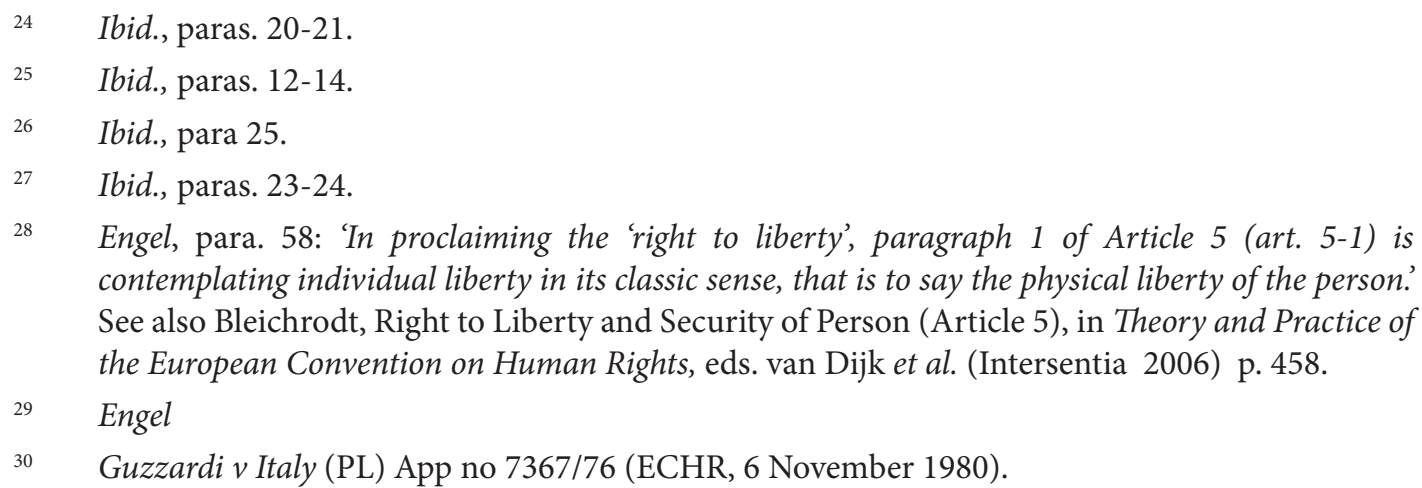


'[I]n order to determine whether someone has been 'deprived of his liberty' within the meaning of Article 5 [...], the starting point must be his concrete situation and account must be taken of a whole range of criteria such as the type, duration, effects and manner of implementation of the measure in question. ' ${ }^{31}$

It is also emphasised that

'[T]he difference between deprivation of and restriction upon liberty is ... merely one of degree or intensity, and not one of nature or substance.. ${ }^{32}$

It follows from these statements that no specific measures infringing on physical liberty have inherent qualities' that qualify them as deprivations of, rather than restrictions upon, liberty. A distinction has to be drawn in each specific case, based on the criteria listed in Engel \& Others and Guzzardi, between infringements on liberty that are deprivations of liberty, and infringements that are mere restrictions.

A common denominator for infringements that amount to deprivations of liberty is that they consist of confinement to a particular place. ${ }^{33}$ The determination of whether or not a deprivation of liberty has taken place rests upon the combined effect of all the factors that constituted the confinement in question. ${ }^{34}$ Relevant factors will be inter alia the degree of coercion that follows from the confinement, the level of police coercion used to enact the confinement, the area of confinement, the frequency and intrusiveness of supervision during the confinement, and the extent of the possibility to have contact with the outside world while confined. ${ }^{35} \mathrm{~A}$ deprivation of liberty will be found by the Court if there is confinement to a particular place for more than a negligible period of time, and if in addition there is one or more 'aggravating factors', distinguishing simple detention from a deprivation of liberty. ${ }^{36}$ An illustrative example is Gillan \& Quinton v the United Kingdom. ${ }^{37}$ In this case, the two applicants were stopped and searched by London police officers under section 44 of the UK Terrorism Act $2000 .{ }^{38}$ One of the applicants was de-

\footnotetext{
$31 \quad$ Ibid., para. 92.

$32 \quad$ Ibid., para. 93.

33 Cline, Deprivation of Liberty: Has the European Court of Human Rights Recognised a 'Public Safety' Exception?, in 29 Merkourios - Utrecht Journal of International and European Law, (Issue 76), p. 29.

$34 \quad$ Guzzardi, para. 95.

$35 \quad$ Cline, p. 29.

36 Ibid. See also Allen, Restricting Movement or Depriving Liberty, in 19 J. Mental Health L (Spring 2009), p. 28.

37 Gillan \& Quinton v the United Kingdom App no 4158/05 (ECHR, 12 January 2005).

$38 \quad$ Ibid., para. 8.
} 
tained for approximately twenty minutes ${ }^{39}$ and the other for about five minutes. ${ }^{40}$ While detained they were entirely denied their freedom of movement. If they had refused to submit to the search, they would have been liable to arrest, detention at a police station and criminal charges. This element of coercion, the Court stated, was indicative $e^{41}$ of a deprivation of liberty within the meaning of Article 5 (1)..$^{42}$ The applicants were confined to the place where the search was carried out, and were not at liberty to leave before it had been carried out. Additional 'aggravating factors' in this case were the fact that body searches were carried out, and the threat of arrest and possible criminal charges, should they have tried to leave without permission from the police.

\section{The Outcome of and Reasoning in Austin in Light of Previous ECtHR Case-Law}

The applicants in Austin were confined to the space within the police cordon at Oxford Circus from approximately 2 p.m. until, respectively, 9.30 p.m., 9.20 p.m., 9.35 p.m. and 8 p.m. ${ }^{43}$ Confinement in itself is not sufficient to state that the measure taken went beyond a restriction of the applicant's ability to move freely. There were, however, at least three 'aggravating factors.' Firstly, there was the duration of the confinement, which was between six and eight hours for the respective applicants. Secondly, there was the condition under which the confinement was carried out. The weather was cold and wet, and there were no access to food, drink or toilet facilities. (It is acknowledged by the Court that these two factors 'point towards' a deprivation of liberty.) ${ }^{44}$ Thirdly, had the applicants tried to break out of the cordon, they would undoubtedly have faced arrest and criminal charges for disobeying police orders. Undeniably, the outcome of Austin would have been that the confinement was found to be a deprivation of the applicant's liberty under Article 5 (1), had the Engel- and Guzzardi-criteria been applied in the same way as in previous cases.

The criteria established in Engel \& Others and Guzzardi are explicitly upheld in Austin. ${ }^{45}$ However, a new aspect is introduced in the Court's application of two of the criteria from Engel and Guzzardi, namely in the application of the criterion the type of the measure in

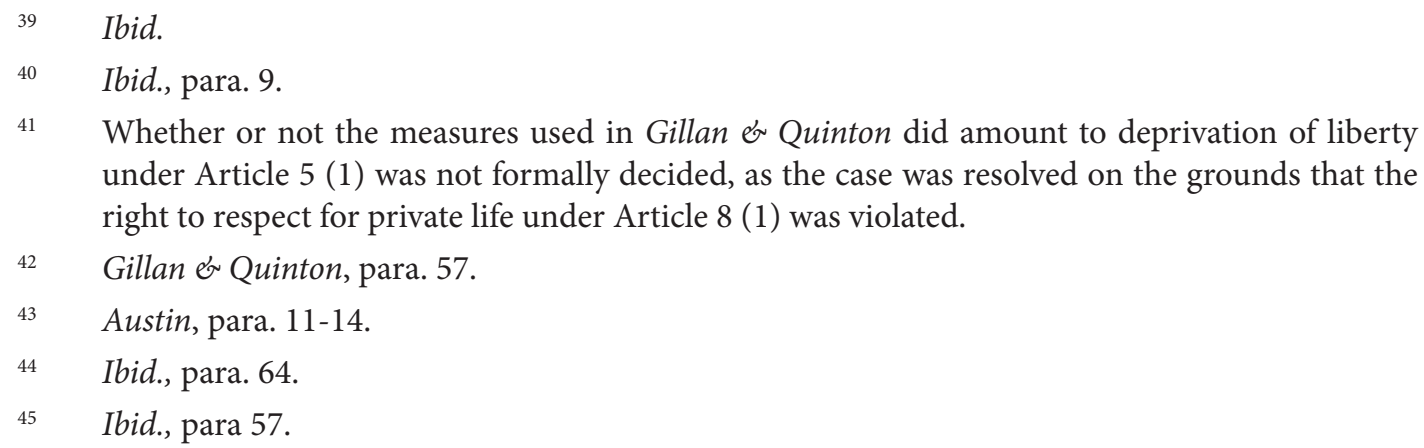


question' and the criterion 'the manner of implementation of the measure in question.' Previous case law has taken the stance that the purpose behind the measure is not relevant when deciding if there has been a deprivation of liberty. The purpose of the measure is relevant only in deciding whether a deprivation of liberty can be justified under Article 5 (1) (a-f). ${ }^{46}$ This point of view is held forth also in Austin. But in Austin, the Court states that when considering whether or not the 'type' and 'manner of implementation' makes the measure in question a deprivation of liberty, these requirements enable it

'to have regard to the specific context and circumstances surrounding types of restriction other than the paradigm of confinement in a cell. ${ }^{47}$

It was this new approach that made it possible for the Court to reach the result that the kettling' in Austin did not constitute deprivation of liberty.

\section{The Argumentation in Austin in Light of the Principle of Ne- cessity}

\subsection{Introduction}

The majority judges' argumentation in Austin can be divided into two parts addressing arguments on different levels. One level consists of arguments stating why there was a need to approach the interpretation of the term 'deprived of his liberty' in a way that differed from previous interpretations. On the same level are the arguments for why the new approach could and should be based on the 'context and circumstances'-model. The other level consists of arguments regarding the nature and consequence of the 'context and circumstances' in this particular case.

The arguments which introduce the new approach will be discussed first. It will be suggested that in this particular case there was good reason to take on a new approach to the interpretation of what constitutes a 'deprivation' of liberty, but that these reasons were quite different from those stated by the Court. Secondly, the material content of the 'context and circumstances'-approach will be discussed. The main focal point here will be to show how the arguments presented by the Court fit into a pattern of argumentation related to the principle of necessity, and consequently also how the arguments relate to national police law.

Norms derived from the principle of necessity can have different functions in positive law. The function of interest here is 'necessity' invoked as legal basis for infringements on individual rights and freedoms made by state authorities. One of several phrases used for

\footnotetext{
$46 \quad$ Ibid., para. 58.

$47 \quad$ Ibid., para. 59.
} 
describing norms derived from the principle of necessity is 'the defence of necessity.' This term may first and foremost be applicable to 'necessity' as a ground of defence in criminal law, but it would also seem to be an adequate term for describing 'necessity' invoked as legal basis by authorities. If 'necessity' could not be invoked, the infringement would constitute not only breach of the legal right or freedom in question, but would very possibly also constitute a criminal offence, such as unlawful detention.

Accordingly, state authorities acting in a way that constitutes an infringement will be in need of a 'defence' suited to justify their actions. When in the following it is discussed how the argumentation of the Court can be seen as related to the principle of necessity, the relation will be referred to as being one between the 'context and circumstances'-approach and the defence of necessity.

\subsection{The Court's Arguments for taking a new Approach to the Interpretation of 'Deprived of his Liberty'}

The Court offers two main sets of arguments to support its view that a new approach to the interpretation of the term 'deprived of his liberty' was warranted. The first concerns the fact that it was impossible 'to identify a moment when the measure changed from what was, at most, a restriction on freedom of movement, to a deprivation of liberty,' and that 'the applicants did not contend that, when the cordon was first imposed, those within it were immediately deprived of their liberty. ${ }^{48}$ As pointed out by the dissenting judges in connection with the first of these statements, it is unclear what this observation means. ${ }^{49}$ The meaning must probably be that since the exact moment a deprivation of liberty occurred cannot be established, it must be ruled out that any such deprivation have occurred. The use by the dissenting judges of the word 'observation' is here very accurate, because it is nothing more than just that. The observations here put forward by the majority of the Court are not valid arguments when deciding if deprivation of liberty has taken place. Duration is one of the relevant factors, as established in Guzzardi and Engel, but since deprivation of liberty is divided from restriction on the freedom of movement by assessing the 'degree or intensity ${ }^{50}$ of the infringement, based on all the relevant factors, identification of a specific moment when restriction turns to deprivation will never be possible. It may in a given situation be clear that deprivation did not occur instantly after bringing the measure in question to use, and it may be clear that deprivation is a fact when the measure has been upheld for 30 minutes, but one cannot establish a precise moment when this change took place.

\footnotetext{
$48 \quad$ Ibid., paras. $66 \& 67$.

$49 \quad$ Austin, Joint Dissenting Opinion, para. 12.

50 Guzzardi, para. 93.
} 
The second set of arguments is centred on the fact that the situation at hand was new and unique, as compared to earlier cases where the term 'deprived of his liberty' had been interpreted by the Court. Mention was made inter alia of the fact that the police in recent times face challenges unforeseen when the Convention was drafted, have developed new techniques to deal with these challenges, and that 'the measure was imposed to isolate and contain large crowd, in volatile and dangerous conditions.' ${ }^{51}$ This is of course true. 'Kettling' was not in use when the Convention was drafted, and prior to Austin the question of deprivation of liberty had not been considered by the Court in connection with police containment of large crowds. Yet, it is difficult to see how these circumstances could be relevant as reasons for finding a new way to interpret 'deprived of his liberty.' The kind of measure used is of course of relevance, and can as such contribute to the result that an infringement on personal freedom is not a deprivation thereof, but it is of relevance within the method of interpretation already established in previous case-law. The number of people affected by the measure does not in itself warrant a new interpretation. Had each and every one of the 2,000 people inside the police cordon been violent demonstrators, it would have been sufficient to use the established criteria for interpretation, conclude that the kettling' amounted to deprivation of liberty, and declare it in conformity with the Convention under Article 5 (1) subparagraph (b), because all 2,000 had failed to fulfil an obligation prescribed by law. The need for a new approach follows instead from the fact that among the 2,000 there were many innocent passersby, i.e. 'third parties.' As far as these third parties were concerned the kettling' would have been unlawful without a new approach to the interpretation of 'deprived of his liberty'. It was important for the Court to avoid this outcome, as it stated that '[A]rticle 5 cannot be interpreted in such a way as to make it impracticable for the police to fulfil their duties of maintaining order and protecting the public [... ]' 52 This statement is completely in line with 'necessity'-based reasoning in national police law, and so is the solution introduced by the Court, namely the 'context and circumstances'-model: Because of the context and circumstances, there was a need for reinterpreting the term 'deprived of his liberty.' The important circumstance however was not the amount of people involved, but the fact that some of them were third parties.

\subsection{The 'Context and Circumstances'-Approach in Austin and its relation to the 'Defence of Necessity'}

\subsubsection{The Legal Concept of 'Defence of Necessity'}

The legal concept of the 'defence of necessity' consists of two main elements. One element contains norms describing the facts constituting a state of necessity, while the other

Austin, paras. $56 \& 66$.

Ibid., para. 56. 
contains norms laying down requirements for the measure constituting the act of necessity. The particulars of both these elements can differ somewhat from one legal system to another, and may also differ within the same legal system, according to what function the concept is to fulfil. It will be attempted in the following to lay down the particulars for a general legal concept of the 'defence of necessity' as legal basis for actions taken by state authorities against individuals, based on what can be considered as the typical contents of this concept.

On a constitutional level a state of necessity is often called an 'emergency.' Invocation of the defence of necessity as legal basis for infringements on rights and freedoms by state authorities can be seen as a form of 'emergency on a smaller scale.' On the constitutional level the main characteristics of an 'emergency' is the occurrence of a sudden and unforeseen situation that is of an exceptional character, and requires immediate action. In addition this situation must be of a temporal duration, as the aim is to return to the adherence of regular law as soon as possible..$^{53}$ These characteristics of a constitutional 'emergency' seem to be applicable also when defining the state of necessity when the defence of necessity is invoked as the legal basis for actions taken by authorities. In both instances 'necessity' is invoked by authorities as the legal basis for setting individual rights and freedoms aside.

The act of necessity performed by authorities under the legal concept of 'defence of necessity' will be an act that in one way or other curtails, or completely sets aside, individual rights or freedoms protected by law. The central element when formulating the requirements applicable to the act of necessity will be the balance between the damage that must be expected from the sudden and unforeseen situation, and the infringing effect of the act that is being used to suppress this situation. Is the situation (i.e. the state of necessity) grave enough to outweigh the infringement carried out on a right or freedom protected by law? Given the serious implications of setting aside rules whose function it is to protect individuals from arbitrary use of coercion, such action cannot be easily justified. The norm for balancing these opposing interests will therefore have to contain some form of qualifying element, for the act in question to be in accordance with the principle of necessity, as expressed through the legal concept of the defence of necessity. The content of the norm will have to be that the averted risk must outweigh the suspension of rights and freedoms by a considerable margin, e.g. that the danger to be averted must be 'considerably more significant' than the infringement on rights taking place. A smaller margin in favour of suspension cannot be sufficient, as this would amount to disregard of the requirement of proportionality, inherent in the principle of necessity. Another requirement is that the measure chosen must be the least intrusive of those available and

53 Gross and Ní Aoláin, Law in Times of Crisis - Emergency Powers in Theory and Practice (Cambridge University Press 2006), p. 172. 
sufficient to avert the danger. The requirement of the least intrusive measure' also implies that the measure in question must be used only to the degree that is necessary, in terms of quantity and duration.

\subsubsection{The Argumentation in the Austin Judgment}

When reviewing the arguments used by the ECtHR in Austin, it will first be pointed out that a consideration of the 'context and circumstances' as carried out by the Court can, in general, be viewed as closely connected with the concept of 'defence of necessity.' Secondly, an account will be given of how the Court's argumentation regarding 'context and circumstances' can be said to follow a line of argumentation closely resembling the defence of necessity in this particular case.

\subsubsection{The General Relation between 'Context and Circumstances' and the Defence of Necessity}

As was mentioned in part 8 above, the majority in Austin upholds the point of view established in earlier case-law that 'purpose' is not relevant when deciding if a deprivation of liberty has taken place. It seems clear that, would 'purpose' have been considered relevant, it would have opened the door for incorporating the concept of 'necessity' into Article 5 (1). In principle, any purpose could then be seen as a relevant justification, providing it was 'necessary' for authorities, according to the particulars of the defence of necessity, to pursue the purpose in question. However, the Court's new interpretation of the relevant criteria of 'specific context and circumstances,' fulfils in effect exactly the same function. 'Context' and 'circumstances' are in themselves criteria that relate to necessity. The reason why both context and circumstances are seen as relevant is that these factors are decisive in assessing whether or not carrying out the measure is necessary, and in assessing in which way it is necessary to implement it, in a particular context, and under particular circumstances. When considering the 'purpose' of a measure, a balancing is performed between the importance of achieving the purpose in question on the one hand, and the degree of infringement on a right or freedom caused by using the measure on the other. Exactly the same balancing must take place when the question is whether the type and manner of implementation of the measure is such that the 'specific context and circumstances' make the measure lawful, in the sense that it does not constitute deprivation of liberty under the Convention: how important is it to be able to use this measure in this way, considering the context and circumstances, and how significant is the infringement caused by using it? Context and circumstances make the infringement 'necessary' if the infringing effect of the measure is to a sufficient degree outweighed by the remedying effect it will have, e.g. if the remedying effect is 'considerably more significant' than the infringement. 


\subsubsection{The Relation between the Specific 'Context and Circumstances' in Austin and the} Defence of Necessity

When the Court set out to explain why 'the context in which action is taken is an important factor to be taken into account,' it pointed out that situations commonly occur in modern society where the public has to endure restrictions on freedom of movement or liberty 'in the interests of the common good.' The Court stated that it did not consider such restrictions as 'deprivation of liberty' within the meaning of Article 5 (1), as long as certain criteria were met. The criteria which were provided, and found to be met, were as follows. ${ }^{54}$ Firstly, the restriction had to be 'rendered unavoidable.' This can be seen as a further qualification of the norm defining proportionality under the defence of necessity. In the general model of that legal concept, outlined above, proportionality is said to require a danger 'considerably more significant' than the infringement on rights and freedoms following from the measure in question. In declaring that the measure must be unavoidable, the Court can be interpreted as proclaiming that the threshold for proportionality should be even higher when applying the 'context and circumstances'-model than what follows from a general model of the defence of necessity: the deprivation is outweighed by the danger (i.e., the deprivation is 'necessary') only when the danger cannot be averted in any other way. ${ }^{55}$

Secondly, the restriction had to be the result of circumstances beyond the control of the authorities.' This is most certainly a possible way to adapt the particulars of the defence of necessity, even if it is also possible to imagine a legal concept of the defence of necessity that does not include this requirement. ${ }^{56}$ Thirdly, there had to be 'a real risk of serious injury or damage.' By stating this criterion, the Court relates its argumentation to the element of the defence of necessity that requires the state of necessity to be of such a kind that immediate action is warranted. Fourthly, the Court states that the restriction on the freedom movement must be 'kept to the minimum required.' This is an application of the element of the defence of necessity that requires the act of necessity to be used only to

The relevant criteria are stated in Austin, para. 59 and the application of them to the facts of the case are dealt with in para. 66.

55 In general, the requirement of proportionality under the principle of necessity can be seen as an integral part of the concept of 'necessity': the measure in question is 'necessary' e.g. if the threatening danger is 'considerably more significant' than the infringement. When the threshold for what is 'necessary' is raised to a requirement that there must be no other possibilities of averting the danger than to use the measure in question, the question of proportionality stands out as a subject for separate and additional evaluation. Even if the measure is 'necessary' in the sense that there is no alternative, it may still be disproportionate to use it.

56 For example, under Norwegian criminal law, the defence of necessity may in some instances be applicable even if the state of necessity has been created by the defendant himself. In other instances, however, the defendant will not be able to successfully invoke the defence of necessity if he is to be blamed for the occurrence of the danger. See Andenæs, pp. 181-182. 
the degree that is necessary. The ECtHR does not explicitly mention any equivalent to the requirement that the state of necessity must occur suddenly and be unforeseen, but from its rendering of the facts found by the English High Court, which the ECtHR based its decision on, ${ }^{57}$ it is clear that such a criterion was found to be fulfilled: because the gathering at Oxford Circus took place two hours earlier than expected, the police were taken by surprise, and therefore had no choice but to resort to putting up a cordon. ${ }^{58}$

The Court pays very little attention to the fact that three of the four applicants in Austin were innocent passersby, who had nothing whatsoever to do with the occurring public disturbances, but who was nonetheless trapped inside the police cordon for several hours. It is simply stated that this difference is not relevant to the question whether there was a deprivation of liberty. ${ }^{59}$ As we have seen, exactly the opposite is true. The fact that 'third parties' were affected was the key element in the need for an alternative approach. The need for invoking 'context and circumstances' only arises if the persons whose rights and freedoms are infringed upon have done nothing illegal (or if, as in this case, it is impossible to separate offenders from innocents).

This dismissal of the difference between 'disturbers' and 'non-disturbers' is sharply criticised by the three dissenting judges. ${ }^{60}$ The criticism seems well founded. Even if there was good reasons to find the use of 'kettling' compatible with the Convention through the 'context and circumstances'-model, one would expect that it was at least considered whether the outcome of the concrete balancing of interests should be affected by the fact that third parties were involved. Under national police law such considerations would have to be carried out, and it would normally be highly relevant for the question of proportionality whether the measure in question was directed against 'offenders' or third parties. When directed against third parties it would also be relevant if their personal freedom was infringed upon in order to uphold their own security or in order to safeguard the interests of others (see parts 4.2 and 4.3 above). 'Necessity'-based norms can make the use of infringing measures against third parties legal in general, but quite another thing is whether such use is proportional in the concrete situation in question. The legal principles which lead to this situation under national law are highly relevant also under Convention law, and in some instances the need to differentiate may even follow from the Convention itself. For example, if the situation at Oxford Circus was so serious that the lives of the innocent passersby were in danger (something which is difficult to assess from the description of the facts), this would be a strong argument bolstering the idea that the use of a police cordon did not amount to a deprivation of liberty, as it could

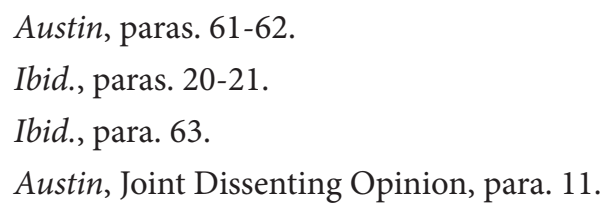


be seen as a means of protecting the right to life of these third parties under Article 2 of the Convention. It is therefore unfortunate that the Court chose to see the fact that innocent passersby were affected as irrelevant for the balancing performed under the 'context and circumstances'-model.

\section{The impact of the Austin decision}

The last question to be addressed in this article shall be the following: To what extent can the Austin decision be said to have altered the state of law regarding deprivations of liberty under Article 5 (1) of the Convention?

First of all it must be emphasized that Austin does not establish a precedent for a legal rule to the effect that use of police cordons generally, and the enclosure of people therein for seven or eight hours, does not amount to deprivation of liberty under Article 5 (1). Such was the concrete outcome of the case, but this outcome was a result of the Court's determination of the facts in the case, based on its assessment of the evidence, and of the Court's balancing of the conflicting interests. The 'context and circumstances'-model was the foundation for the balancing, but had the facts (i.e. the 'context' and the 'circumstances') been different, the outcome of the balancing could also have been different. Legal decisions reached by balancing will always, as opposed to decisions reached by the application of rules, be of a concrete and specific nature. ${ }^{61}$ Austin, therefore, does no more than establish a legal basis for use of the 'context and circumstances'-model.

An important aspect regarding the impact of Austin is whether it opens the way for a general use of the 'context and circumstances'-model in every instance where infringing measures used by authorities against individuals are not covered by any of the subparagraphs in Article 5 (1). The dissenting judges expressed their fear that the judgement would imply that every legitimate public-interest purpose would be sufficient for a certain measure not to be considered a deprivation of liberty, as long as the measure in question

${ }^{61}$ Although the degree to which it is specific and concrete will vary, depending on the existence or absence of guidelines defining the proper balance (i.e. the point of proportionality) between the conflicting interests. (The term 'guideline' is here used as a direct translation of the Norwegian term 'retningslinje', see Eckhoff \& Sundby, Rettssystemer - Systemteoretisk innføring i rettsfilosofien (Second ed., Tano 1991), pp. 109 and 124-125.) If for example a guideline exists stating that a certain restriction on personal liberty can only be legal where the occurrence of serious public disturbance is almost certain, this guideline in most cases (but not in all) will lead to the result that the restriction in question cannot be considered proportional. If no such guidelines exist, the outcome of the balancing is completely dependent on a concrete evaluation of 'context and circumstances.' See Barak, Purposive Interpretation in Law (Princeton University Press 2005), p. 179, who calls the two situations 'principled balancing' and 'ad hoc balancing,' respectively. The balancing carried out by the Court in Austin was a principled one, since it had established the guideline that use of a police cordon under the 'context and circumstances'model could only be in conformity with the Convention if it was 'rendered unavoidable' (see part 6.2.2 above). 
was held to be necessary. ${ }^{62}$ This fear does not seem to be warranted. As this article has shown, the need for introducing the 'context and circumstances'-model is closely related to the police task of maintaining security and public order. The decision does not have any bearing on possible deprivations of liberty carried out by other branches of authority. Nor does it have any bearing on other areas of police work, e.g. criminal investigations. There should accordingly be no reason to believe that Austin could be the starting point of an undermining of the position that Article 5 (1) (a-f) is exhaustive. What Austin does is to repair a flaw of the Convention, ensuring that certain police measures used while upholding security and public order, which may be legal in Convention states, are also legal under Convention law.

Restricting the significance of Austin to the police task of maintaining security and public order does not, however, constitute clear and well defined limits for the scope of the decision. One problem arises from the fact that the 'deprivation of liberty' carried out by police while maintaining security and public order can take many different shapes. Does the Austin decision mean that all kinds of police measures possibly amounting to deprivation of liberty can be subject to evaluation under the 'context and circumstances'-model, or is the use of this model restricted to certain kinds of measures? A related problem is that the term 'security' can have several different meanings. Not every police measure that can be termed a 'security measure' will necessarily fall under the scope of the 'context and circumstances'-model according to Austin.

In its decision the Court states that 'it cannot be excluded that the use of containment and crowd-control techniques could, in particular circumstances, give rise to an unjustified deprivation of liberty in breach of Article 5 (1). ${ }^{63}$ The Court associates this statement explicitly to 'the use of containment and crowd-control techniques,' but as we have seen, the need for a supplement to the earlier interpretational approach to the term 'deprived of his liberty' cannot be linked to the number of people involved. This need arises from the need of the police to be able to direct certain measures against third parties, even when they amount to the most serious infringements on personal liberty. Elsewhere in the Austin-judgment the majority seem to be opening up for the application of the 'context and circumstances'-model to various kinds of police measures used for the maintenance of security and public order, which are infringing on the liberty of movement. Indeed, the Court gives its support to the view expressed when Austin was decided in the English judicial system, that infringements by the police on personal liberty should be seen as restrictions on, rather than deprivation of, liberty, not only when controlling crowds inter alia in connection with demonstrations and football matches, but also when restricting motorists from leaving their cars after highway accidents, as well as when preventing lo-

62 Austin, Joint Dissenting Opinion, para. 3.

63

Austin, para. 60. 
cal residents from coming to close to a fire or a terrorist incident. ${ }^{64}$ The need for imposing restrictions in situations like these will be the same whether the measures are directed against individuals or against crowds. It is not possible to say how the Court would respond to a situation regarding one or a few innocent third parties. If the connection with crowd-control techniques is upheld, the tension described in part 2 above has only been solved up to a point.

Even if the significance of Austin is not restricted to crowd-control techniques, it can nevertheless hardly apply to all police measures that can amount to deprivation of liberty, and which are related to security and public order. One example of a security measure that seems to fall outside of the scope of Austin is the detention in prison of persons who in the future may come to perform terrorist attacks if not detained. There is in itself nothing in the legal term 'security' which must lead to this conclusion. A 'state of necessity' under the 'context and circumstances'-model may obviously occur also -and not least- as the result of terrorist threats. Why should the use of this model not be relevant in circumstances as precarious as this? The dissenting judges in Austin raised exactly this question in relation to the Court's decision in A. \& Others $v$ the United Kingdom, ${ }^{65}$ as they referred to the ECtHR's unwillingness in the latter case to accept the British government's argument that the interests of the state had to be balanced against the interests of the individual, in a case that was 'even more serious' than Austin. ${ }^{66}$ In A. \& Others the applicants had been detained in prison -some of them for more than three years- because of fears that they could pose a threat against national security, as possible future terrorists. The detention was in accordance with national legislation, but did not come under the scope of Article 5 (1) (f) of the Convention, i.e. detention 'with a view to deportation or extradition'. The detainees could not be deported because no state able to guarantee that they would not suffer treatment contrary to Article 3 (torture or inhuman or degrading treatment) was willing to accept them. ${ }^{67}$ Therefore, the detention was found to amount to deprivation of liberty in breach of Article 5 (1).

The question raised by the dissenting judges in Austin is highly relevant, as it illustrates that a general dividing line between measures that fall respectively inside and outside of the scope of the 'context and circumstances'-model can seem difficult to draw. However, an important aspect of the A. \& Others case is that it deals with individuals whom the authorities feared would commit crimes in the future. They were detained because there was a possibility they could become terrorists. Deprivation of liberty due to unlawful actions are covered by Article 5 (1) subparagraphs (b) and (c), and those subparagraphs

Ibid., paras. 35, 37 and 59 .

65 A. \& Others v. the United Kingdom (GC) App no 3455/05 (ECHR, 19 February 2009).

66 Austin, Joint Dissenting Opinion, para. 6.

67 A. \& Others, para. 166. 
can only come to use if there are clear indications of forthcoming unlawful activity (see part 2 above), which was not the case. In A. \& Others, it was subparagraph (f) that was under consideration, but had the detainees been British citizens, (b) and (c) would have been the relevant alternatives, and the strict views of the Court on the application of these subparagraphs with regards to future violations of the law, would have ruled out their use ${ }^{68}$ Austin does not alter this situation. It is not the purpose of the 'context and circumstances'-model to make room for an expansion of the use of deprivation of liberty under the Convention, with regards to future violations of obligations prescribed by law. Instead its function is to bring Convention law in accordance with national police law in Convention states which may allow serious infringements on personal freedom, in the form of police measures against persons who are not connected with any kind of wrongdoing, neither in the present or in the future.

It may seem strange that balancing under the 'context and circumstances'-model shall be available when infringing on the liberty of individuals who are in no way connected to any past, present or future wrongdoings, but not when a measure to the similar effect is directed against someone who may become a terrorist. The explanation is that Article 5 (1) itself deal with individuals that can with some degree of certainty be suspected of past, present or future unlawful actions. There is no reason why the 'context and circumstances'-model should be allowed to alter positive Convention law regarding the use of deprivation of liberty in cases where someone is suspected of being able to commit unlawful actions in the future. When it comes to deprivation of liberty directed against individuals who are not in any way connected with unlawful actions, however, there is a void in the Convention. It simply does not foresee any legitimate need to use deprivation of liberty in such cases. That such need can exist, in the interest of the individual himself or in the interest of the common good, has been shown above. The dissenting judges of Austin are accordingly asking the wrong question when they wonder why 'context and circumstances' was relevant in Austin but not in A. \& Others, despite the situation in the latter case being 'even more serious.' For the 'context and circumstances'-model to be available the situation must indeed be 'serious', in the sense that a situation amounting to a state of necessity must exist. But whether the situation is 'very serious' or less serious' is not the decisive factor when assessing a state's possibility to make use of the 'context and circumstances'-model according to Austin. 


\section{Conclusion}

Deprivation of liberty is among the most serious encroachments that can be made by authorities on individuals' human rights. It is therefore highly understandable that the use of measures to this effect has been singled out in Article 5 (1) as being compatible with the Convention only when certain strict and detailed conditions are met. In most areas of law governing the relation between individuals and authorities these conditions will not give rise to serious problems. In the field of police law dealing with security and public order, however, the situation is different. This is a field of law which is not always suited for the kind of regulation that Article 5 (1) has to offer. The principle of necessity can be seen as constituting the core of national police law in this area, and national legislation on the subject can be read as attempts to describe the conditions under which police measures are necessary and proportionate. Article 5 (1) attempts the same, but without the supplement from unwritten 'necessity'-based norms that national police law may have to offer. By using the legal technique of restrictive interpretation as a foundation for introducing the 'context and circumstances'-model, the ECHR has created a much-needed way to solve the tension this situation gives rise to. According to the judgment's justification given by the Court itself, the use of the model shall be restricted to crowd-control techniques, but as we have seen, it is a model that has the capacity to solve the entirety of the tension arising with regards to third parties between national police law and Article 5 (1) of the Convention. 